DOE/PC/95231-37

DIST. CATEGORY UC-112

UTSI-02-04

\title{
TECHNICAL PROGRESS REPORT \\ FOR \\ UTSI/CFFF MHD PROGRAM COMPLETION \\ AND RELATED ACTIVITY
}

For The Period

October 1, 2002 - December 31, 2002

Work Performed Under Contract No. DE-AC22-95PC95231

Prepared for:

The United States Department of Energy

\author{
Prepared by \\ The University of Tennessee \\ Space Institute \\ Energy Conversion Research and Development Programs
}




\section{DISCLAIMER}

This report was prepared as an account of work sponsored by an agency of the United States Government. Neither the United States Government, nor any agency thereof, nor any of their employees, makes any warranty, express or implied, or assumes any legal liability or responsibility for the accuracy, completeness, or usefulness of any information, apparatus, product, or process disclosed, or represents that its use would not infringe privately owned rights. Reference herein to any specific commercial product, process, or service by trade name, trademark, manufacturer, or otherwise does not necessarily constitute or imply its endorsement, recommendation, or favoring by the United States Government or any agency thereof. The views and opinions of authors expressed herein do not necessarily state or reflect those of the United States Government or any agency thereof. 
EXECUTIVE SUMMARY. iv

TASK 1 - FACILITY MAINTENANCE AND PROPERTY MANAGEMENT ….................................... 1

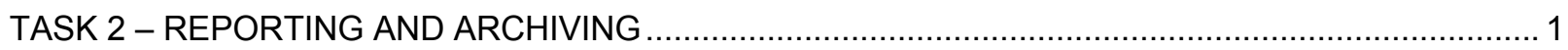

TASK 3 - SITE ENVIRONMENTAL COMPLIANCE AND REMEDIATION ....................................... 1

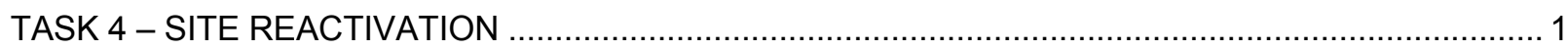

TASK 5 - DISASSEMBLY AND DISMANTLEMENT (D\&D) OF THE CFFF .................................... 1

TASK 6 - ADVANCED TECHNOLOGY, RESEARCH, DEVELOPMENT AND ENGINEERING FOR OTHER FEDERAL OR DOE PROGRAMS …........................................................ 2

Subtask 6.02 - Evaluation of Methods for Application of Epitaxial Buffer and Superconductor Layers .... 2

Subtask 6.03 - Coated Conductor Development and Program Management..................................... 2

Subtask 6.04 - Optimum Coated Conductor.................................................................................... 2

Subtask 6.05 - Cost/Performance Analyses of Potential Manufacturing Processes............................. 2

Subtask 6.06 - Development of Real Time Process Control Using In-Situ Diagnostics ......................... 2

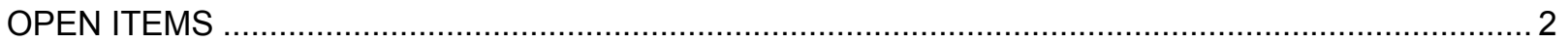

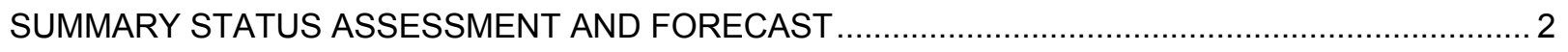

OCTOBER 1, 2002 - DECEMBER 31, 2002, QUARTERLY VARIANCE REPORT ............................. 3 


\section{EXECUTIVE SUMMARY}

Maintenance work on the DOE CFFF facility and other related government property is no longer authorized under this contract in accordance with the DOE-UT Settlement Agreement. Environmental remediation preservation of the facility continued. Government property has been transferred to UTSI as owner which frees up many items for proper disposal. Actions are underway to dispose of other wastes, and control pests and water at the DOE CFFF.

Groundwater remediation activities as mandated by the Tennessee Department of Environment and Conservation (TDEC) continued throughout the quarter. A contract was awarded to an environmental consulting company to drill and sample three additional groundwater wells adjacent to the CFFF property. A report on this activity, with results of the sample analysis, has been sent to the TDEC. 


\section{TASK 1 - FACILITY MAINTENANCE AND PROPERTY MANAGEMENT}

In September 1998, a stop-work order was issued for work activity in the DOE Facility maintenance area. Work to administer government-owned property continued.

On September 22, 1999, Department of Energy and the University of Tennessee signed a SETTLEMENT AGREEMENT resolving all claims and property accountable under Tasks 1-5.

\section{TASK 2 - REPORTING AND ARCHIVING}

October, November and December, 2002 Monthly Reports were submitted.

The Quarterly Key Staffing Report for the period July-September, was submitted on October 10, 2002.

Quarterly Technical Progress Report for the period July 1, 2002 through September 30, 2002, was submitted on October 14, 2002.

\section{TASK 3 - SITE ENVIRONMENTAL COMPLIANCE AND REMEDIATION}

UTSI shall continue implementation and compliance with the State of Tennessee approved plan for groundwater remediation. UTSI shall remove from the site, and properly dispose of, all industrial type non-hazardous wastes. In addition, UTSI shall properly remove all asbestoscontaining cooling water tower materials and dispose of these materials properly. In addition, UTSI shall continue the monitoring and treatment of holding pond effluent per the site Water Discharge Permit with the State of Tennessee.

The Discharge Monitoring Reports (DMRs) for October, November and December 2002, were prepared and submitted to the Tennessee Department of Environment and Conservation (TDEC).

TVG Environmental, Inc. (Nashville, TN) conducted the first of two contracted sampling events for five (5) groundwater wells adjacent to the Coal Fired Flow Facility. The five wells selected for sampling were designated by TDEC based on their review of previous sampling results. TVG issued their report in December (Groundwater Monitoring Report dated December 16, 2002) with copies to TDEC and UTSI. Information copies will be provided to DOE in January, 2003. The second sampling event is scheduled for May, 2003. No action is expected from TDEC until after the results of the May sampling event have been reported and evaluated.

\section{TASK 4 - SITE REACTIVATION}

No work was scheduled or performed

\section{TASK 5 - DISASSEMBLY AND DISMANTLEMENT (D\&D) OF THE CFFF}

No work was scheduled or performed 
TASK 6 - ADVANCED TECHNOLOGY, RESEARACH, DEVELOPMENT AND ENGINERING FOR OTHER FEDERAL OR DOE PROGRAMS

Subtask 6.02 Evaluation of Methods for Application of Epitaxial Buffer and Superconductor Layers

No Activity.

Subtask 6.03 Coated Conductor Development and Program Management

Discontinued effective September 30, 1999.

Subtask 6.04 Optimum Coated Conductor

No Activity.

Subtask 6.05 Cost Performance Analysis of Potential Manufacturing Processes

Discontinued effective August 31, 1999.

Subtask 6.06 Development of Real Time process Control using In-Situ Diagnostics

Discontinued effective September 30, 1999.

\section{OPEN ITEMS}

January 2000 - December 2000 Monthly Technical Progress Reports January 2001 - December 2001 Monthly Technical Progress Reports January 2002 - December 2002 Monthly Technical Progress Reports October -December 1999 Quarterly Technical Progress Report January - December 2000 Quarterly Technical Progress Reports January - December 2001 Quarterly Technical Progress Reports January - September 2002 Quarterly Technical Progress Reports Kevin Trembath's Thesis Topical Report, "Statistically Designed Experimental Study of Sol-Gel Based Film Coating Scheme for High Temperature Superconductors and Buffer Materials and Related Manufacturing Process Cost Evaluation" submitted August 31, 2000.

\section{SUMMARY STATUS ASSESSMENT AND FORECAST}

Environmental restoration activities at the CFFF will continue and funding to cover these activities will be continued in accordance with the SETTLEMENT AGREEMENT.

Contract reporting requirements are being met on time. Future contract reporting requirements need to be reviewed and modified in accordance with the SETTLEMENT AGREEMENT. 
OCTOBER 1, 2002, THROUGH DECEMBER 31, 2002, QUARTERLY VARIANCE REPORT Planned vs. Actual Expenditures

(thousands of dollars)

$\begin{array}{cccc}\text { TASK } & \text { PLANNED } & \text { ACTUALS } & \text { VARIANCE } \\ 1 & 0.0 & 0.0 & 0.0 \\ 2 & 0.0 & 0.0 & 0.0 \\ 3 & 17.1 & 3.0 & 14.1 \\ 4 & 0.0 & 0.0 & 0.0 \\ 5 & 0.0 & 0.0 & 0.0 \\ 6 & 0.0 & 0.0 & 0.0 \\ \text { TOTALS } & 17.1 & 3.0 & 14.1\end{array}$

\section{COST ELEMENT \\ DIRECT LABOR \\ FRINGE BENEFITS \\ EQUIPMENT \\ EXPENDABLE MATERIAL OUTSIDE CONTRACTS \\ TRAVEL}

TOTAL DIRECT COSTS

INDIRECT COSTS

TOTAL

\section{0}

0.0

0.0

0.0

11.6

0.0

11.6

5.5

17.1
0.0

0.0

0.0

0.0

2.0

0.0

2

1.0

4.5

14.1

Planned vs. Authorized Funding Cumulative

Task

1
2
3
4
5

SUBTOTAL

TOTAL

$\begin{array}{rc}\text { PLANNED } & \text { AUTHORIZED FUNDING } \\ 1495.2 & 1495.2 \\ 574.0 & 574 \\ 557.2 & 557.2 \\ 0.0 & \\ 0.0 & \\ 2626.4 & 2626.4 \\ 3820.9 & 3820.9 \\ 6447.3 & 6447.3\end{array}$

